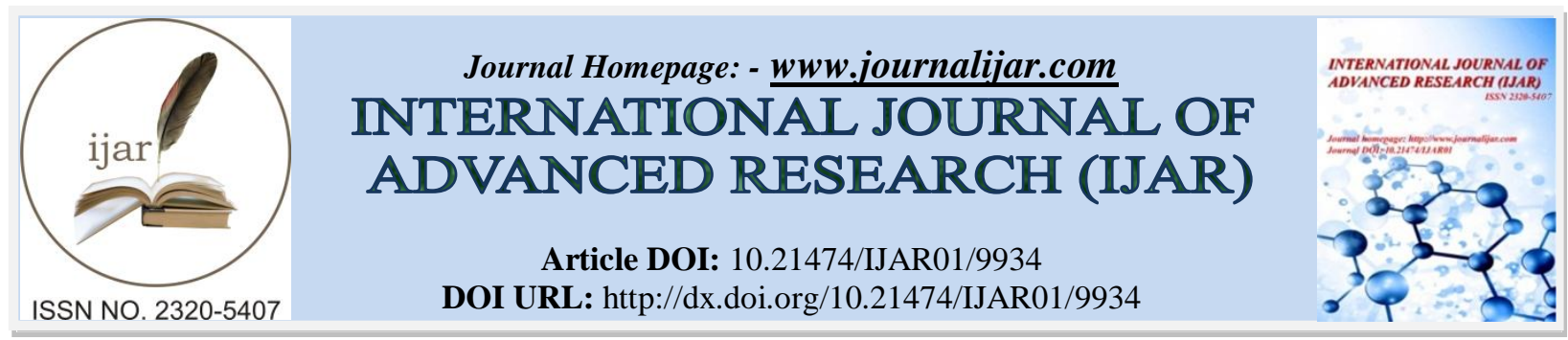

RESEARCH ARTICLE

\title{
SWITCHING CUSTOMERS DIMEDIATE CUSTOMER SATISFACTION AND LOYALTY OF SEA TRANSPORTATION AGENCY IN INDONESIA.
}

\author{
Agung Kwartama $^{1}$, Nizam Jim Wiryawan ${ }^{2}$ and Adek $^{1}$ \\ 1. Maritime Academy AMANJAYA Jakarta. \\ 2. University of Tarumanegara.
}

\section{Manuscript Info}

Manuscript History

Received: 18 August 2019

Final Accepted: 20 September 2019

Published: October 2019

Key words:-

Service Quality, Customer Relationship

Marketing, Attractiveness, Customer

Satisfaction, Customer Loyalty.

\begin{abstract}
The purpose of this study is to analyze the influence of Service Quality, Customer Relationship Marketing, and Attractiveness, on Customer Satisfaction and Customer Loyalty at sea transportation companies in Jakarta Province Region. The research design used in this study is causal design which explains the causal relationship. The research location is in Jakarta Province while the research objects are 10 sea transportation companies in Jakarta Province with 250 customers. The sample selection used nonprobability sampling. This dissertation draft used primary data from questionnaire filled out by the respondents. The tools of analysis of the research are descriptive statistics using SPSS and hypothesis testing by Structural Equation Modeling (SEM) using Lisrel. The results of hypothesis testing showed that : 1) the Organization Culture has not significant effect on Performance, 2) the Organizational Culture has positive and significant impact on Job Satisfaction, 3) the Organizational Culture has positive and significant impact on Achievement Motivation, 4) the Organizational Culture has positive and significant impact on Organization Commitment, 5) Job Satisfaction has not significant effect on Performance, 6) Job Satisfaction has not significant effect on Organization Commitment, 7) Organization Commitment has not significant effect on Performance, 8) Achievement Motivation has positive and significant on Performance, and 9) Achievement Motivation has positive and significant on Jobs satisfaction. The descriptive analysis shows that the level of Service Quality, CRM, Attractiveness, Customer Satisfaction, and Customer Loyalty is at positive level.
\end{abstract}

Copy Right, IJAR, 2019,. All rights reserved.

\section{Introduction:-}

Indonesia is a fast developing country and has enormous natural resources, so the role of transportation services both land, sea and air is needed, especially to support the high level of local and international trade. The implementation of free trade in several regions of Indonesia has resulted in a sharp increase in the flow of goods from or to Indonesia, and being able to create a national stability of the country which has an impact on international trade which also encourages industrialization, transportation progress, globalization, and the presence of multinational companies and reduces the boundaries of a country in carrying out business (Davey, 2005).

Corresponding Author:-Agung Kwartama.

Address:- Maritime Academy AMANJAYA Jakarta. 
This proves that free trade activities as well as international trade through exports and imports can affect the welfare of the people in Indonesia (Sabraruddin, 2015). Related to this, it is needed transportation facilities in the transportation of goods that are efficient and effective (Shin, Roh, and Hur, 2018) ). very important in order to create operational costs of transportation at a minimum level, so that it creates a climate of intense competition among fellow agency companies. As an implication, the emergence of consumer behavior one of which is the movement of consumers. That is because consumers have many choices to obtain the same type of service but with different qualities of alternative appeal and create competition that is open to entrepreneurs. to seize international market share in sea transportation services, causing local entrepreneurs to be more creative, efficient and create alternative attractions in the business so that it can survive long-term (Indonesia Maritime, 2011) and consumers do not desire and are interested in moving other agent services. The results of the preliminary study are also relevant to the results of the research of Mosavi, Sangari and Keramati (2018) who find that consumers' desire to move is influenced, among others, by customer satisfaction and loyalty.

While the results of research by Chen and Lee (2008) state that service quality has an effect on satisfaction, but has no effect on loyalty. Satisfaction and switching costs affect loyalty, and satisfaction affects switching costs. Likewise, Yildiz (2017) in Turkey used 460 questionnaires spread across cargo companies as samples. The results show that service quality has an effect on trust and satisfaction, trust and satisfaction have an effect on loyalty, and loyalty has an effect on the behavior of giving information by word of mouth as Power attract alternatives based on long-standing consumers.

While the findings of $\mathrm{Hu}$ and Huang (2011) in Taiwan, using a sample of The Air Cargo Terminals consumers at Taoyuan International Airport and data processing models using structural equation modeling (SEM), states that service quality has a significant effect on satisfaction and satisfaction has a significant effect on customer loyalty services.

Based on the background of the problem, researchers are interested in conducting more in-depth research and theoretical studies and the objectives of this study are:

1. To analyze the relationship between service quality and customer satisfaction?

2. To analyze the relationship between service quality and loyalty?

3. To analyze the relationship between relational marketing to customer satisfaction?

4. To analyze the relationship between relational marketing and loyalty?

5. To analyze the relationship between relational marketing and customer movement?

6. To analyze the relationship between alternative attractions to customer satisfaction?

7. To analyze the existence of an alternative attraction relationship to loyalty?

8. To analyze the relationship between customer satisfaction and customer movement?

9. To analyze the relationship between loyalty and customer movement?

\section{Literature Review \\ Customer Movements}

Displacement of customers proposed by Kim, Park and Jeong (2004), namely the severance of the relationship between the service provider and the customer (dissolution termination) or as a customer transfer to another service provider (switching migration). The transfer of customers as the replacement of old service providers with new service providers according to research (Ahn, Han, and Lee, 2006; Colgate and Hedge, 2001). While Bansal, Taylor and James (2005) identified that the quality of service provided was the reason for the formation of customer satisfaction and movement. Bansal, Taylor and Yanik (2005) state that individual characteristics in customer movement include: (1) Attitude of non-movement (attitude); (2) Social influences or subjective norms (subjective norms); (3) Switching costs; (4) Prior switching behavior; and (5) Variety in seeking (variety seeking). In the research of Roos et al. (2004) concluded that customer transfers can be grouped into two, namely internal customer switching with different service types or service systems, and customer switching to different companies (external switching).

In this sea transport agency research, customer movement has several characteristics, namely: (1) customer transfers, so that it impacts the company; (2) has a target of the company's external movement, because the company's external movement causes loss of company revenue or profit and (3) the scope of the move is total. 


\title{
Relational Marketing
}

Relational marketing is an effort to develop an exchange relationship that continues and develops with the company's customers. Based on research by Lin, L-H., Chen, K.K. and Chiu, R-H. (2017). In Gures Research, Nuriye, Seda Arslan and Sevil Yucel (2014) There are five key elements that relational marketing has, namely: (1) Developing core services or products around building customer relationships; (2) Adjust relationships with individual customers; (3) Adding back core services or products with extra benefits; (4) Price by encouraging loyalty; (5) Marketing to employees so that their performance runs well for customers. On the other hand Chattananon and Trimetsoontorn (2009) mention the dimensions of relational marketing, namely: (1) Trust, (2) Commitment, (3) Cooperation (Co-operation), (4) Communication, ( 5) Shared values, (6) Conflict, (7) Power, (8) Behavior (non-opportunistic behavior), and (9) Interdependence. Then in his own research Chattananon uses bonding, empathy, reciprocity, and trust as a dimension of relational marketing.

Based on previous research that relational marketing is an effort made by a company to retain customers by creating two-way communication and managing a mutually beneficial relationship between customers and the company, with indicators: trust, commitment, competence, communication, and conflict handling abilities

\begin{abstract}
Alternative appeal
Zhang et al. (2012) explain that in predicting consumer movements, the existence of alternative attractiveness variables is very important. Consumer movement will be present in the minds of consumers if alternative service providers are available that will be the target of movement. Before moving on, consumers will evaluate the quality of these alternative service providers. It was further explained that the attractiveness or alternative quality is an estimation of consumers towards the likelihood of satisfaction that they will obtain from their relationship with other service providers. Alternative quality is a positive characteristic of other service providers (competitors), which will affect consumers' intention to move.
\end{abstract}

An alternative attractiveness factor from competitor quality is a positive factor from other products that can attract consumers to move to the company / other products called pull factors, namely negative effects that attract consumers to move to companies that provide better services (Bansal, Taylor and James, 2005).

Anderson and Narus (Wu, 2011: 313) identify four alternative dimensions of attractiveness as follows: 1). Number of alternatives available; 2) The level of difference between them; 3) The level of difficulty in understanding it; and 4) the level of difficulty in comparing them.

Based on the description above it appears that the alternative attraction is the quality of services offered by different competitors and is better than the services provided by sea transport service providers that enable consumers to move with indicators: advisor (customer relations), speed of delivery, guarantee of package integrity (the package arrived in good condition), and the quality of the ship (fleet).

\section{Service quality}

Rodriguez et.al., (2017) sees satisfaction as a diagnostic indicator that allows evaluating expectations and measuring consumer behavior. Consumer expectations and perceptions about the level of satisfaction is a dynamic dimension, this means that companies must measure it regularly to monitor and check the gaps generated between them. Bansal, Taylor and James (2005) identified that the quality of services provided was the reason for the formation of customer satisfaction and movement.

Guers et al (2014) concluded that service quality requires five dimensions that accompany it, as follows:

1. Reliability (dependable and accurate performance)This dimension relates to the company's ability to provide accurate services from the first time without making any mistakes and delivering services in accordance with the agreed time;

2. Physical evidenceThis dimension relates to attractiveness, physical facilities, equipment and materials used by the company and the appearance of employees;Responsiveness (promptness and helpfulness)

3. This dimension relates to the willingness and ability of employees to help consumers and respond to their requests, as well as informing when services will be provided and then providing services quickly;

4. Guarantees (credibility, security, competence and coutesy)This dimension with regard to the behavior of employees can lead to consumer confidence in the company and the company can create a sense of security for its customers. Guarantees also mean that employees are always polite and master the knowledge and skills needed to handle every customer question or problem. 
5. Empaty (Easy access, good communication and customer understanding)This dimension means that some companies understand the problems of consumers and act in the interests of consumers, and pay attention to consumers and have comfortable operating hours).

Based on the description above according to the author, it can be concluded that the quality of service is the overall features and characteristics of the superior product or service and influences its ability to satisfy the needs of consumers stated in the indicators in

1. Reliability

2. Respondsiveness

3. Assurance

4. Emphaty

5. Tangibles

\section{Consumer Satisfaction}

Giese and Cote (2013) mentioned that there are several common components related to customer satisfaction, namely: (1) emotional or cognitive responses. In relation to the response perspective, emotional approaches are more popular because cognitive approaches can overlap with the domains of constructive determinative processes and customer satisfaction; (2) special focus such as expectations, products, experience consumption ; and (3) certain times, such as after consumption, after choice, based on accumulated experience.

Plinke (2015) also identified several dimensions of customer satisfaction, namely: (a) satisfaction with contract fulfillment, namely products such as function, reliability, safety, aesthetics, economic efficiency and services such as being valued for money, fast, useful, and (b) satisfaction with exchange processes such as respect, courtesy, sincerity, friendliness, understanding, and helping with complaints. Meanwhile, according to Chan et.al (2003) that there are three aspects that need to be disclosed in measuring satisfaction, namely (1) overall satisfaction, which is commonly used in surveys and research as the only indicator; (2) confirmation of expectations, i.e. the degree to which performance exceeds or equals expectations; (3) comparison of ideal conditions, i.e. creative performance of ideal products based on consumers

Based on the description above, it appears that customer satisfaction is a feeling of pleasure or disappointment from consumers after comparing the expectations of a product / service with the performance of the product / service, with indicators: 1) Price, 2). Ease, 3). Benefits 4). Consumer relations with service providers, and 5). Willingness to recommend services.

\section{Loyalty}

According to Kotler and Keller (2012), loyalty is a strongly held commitment to buy again or subscribe to certain products or services in the future despite the influence of the situation and marketing efforts that have the potential to cause behavioral shifts. "Loyalty (alwala ') in an Islamic perspective for companies need to know the different behavior of consumers so that the products offered can be well received. Whereas Griffin and Ebert, (2017), stated that loyalty is characterized by trust, commitment, competence, communication, and conflict handling abilities. If these conditions can be met and maintained well, and get a positive response from consumers, then this will affect the increase in loyalty reflected in word of mouth communication, non-moving behavior, non-complaining behavior, willingness to pay more, repeat purchase, retention, and referalls.

Based on the description above, the researcher hypothesizes that loyalty is a form of behavior from decision-making units or customer commitment to use sea transportation services continuously, with indicators:

1. Word of mouth communication,

2. Behavior does not move,

3. Not complaining behavior,

4. Willingness to pay more,

5. Repeat purchase,

6. Retention, and

7. Referrals 


\section{Research Hypothesis. \\ Research Model}

This study will focus primarily on customer satisfaction and loyalty in shipping company services and idenfying factors that influence it, such as alternative attractiveness and service quality on customer satisfaction and loyalty. In addition, researchers present the conceptual model contained in the Figure below;

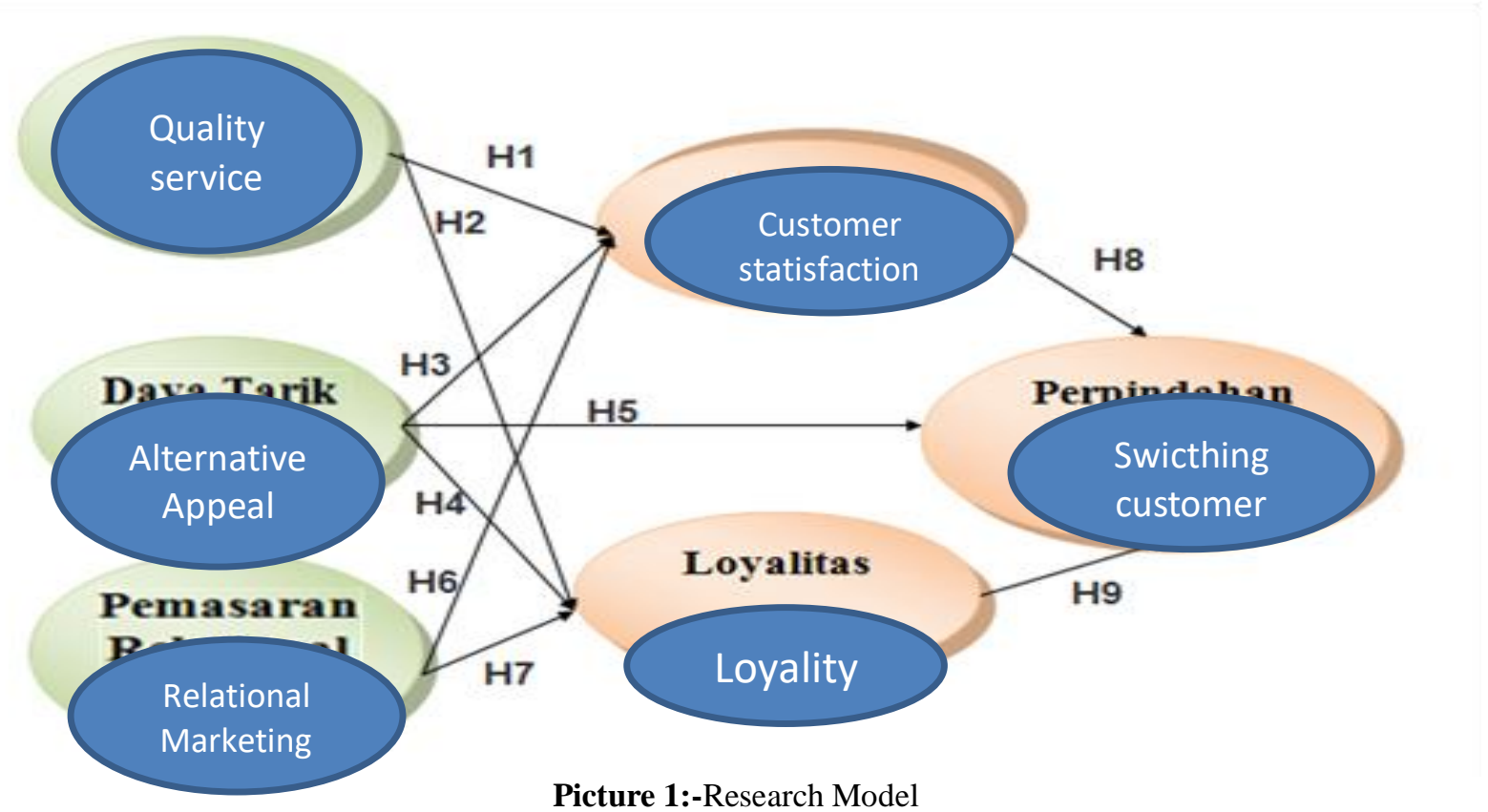

\section{The hypothesis of this research model}

Based on the objectives and the research model adopted 9 hitpotesis were made related to alternative attractions, service quality, relational marketing, customer satisfaction, loyalty and customer movement.

1. H1 There is an influence of service quality on customer satisfaction

2. $\mathrm{H} 2$ There is an influence of service quality on loyalty

3. H3 There is an influence of alternative appeal to customer satisfaction

4. H4 There is an influence of alternative appeal to loyalty

5. H5 There is an alternative attraction effect on customer movement

6. H6 There is an influence of relational marketing on customer satisfaction

7. H7 There is an influence of relational marketing on loyalty.

8. H8 There is an influence of customer satisfaction on customer movement

9. H9 There is an effect of Loyalty on customer movement

\section{Research methods:-}

The object of this research is alternative attractiveness variables, relational marketing, service quality, customer satisfaction, loyalty and customer movement. The population in this study are consumers of sea transportation services in Indonesia. The number of samples used is at least 250 samples. The sampling technique used is probability sampling, where the respondent is the best party to be used as the sample of his research (Sekaran and Bougie, 2013), and the sample analysis method uses the Random Sampling Cluster.

This type of research uses quantitative and descriptive, the aim is to provide or describe a situation or phenomenon that is happening now by using scientific procedures to answer the problem in actual terms. Primary data sources were obtained from the results of distributing questionnaires and interviews with users of logistic services from January 1 to June 28, 2018, while secondary data in the form of literature studies, websites, internet and journals discussed alternative attractions, service quality, relational marketing, customer satisfaction, Loyalty and customer movement. Measurement of each variable uses a Likert scale with the Structural Equation Modeling analysis method. 


\section{Research results and discussion:- \\ Descriptive analysis results}

Analysis of the descriptive statistical results processed from the questionnaire regarding the indicators answered by the respondent, presented in the form of a percentage or proportion has found indicator questions that need to be discussed further, because they have not been positively assessed or are still considered to be problematic, including:

1. Customer-related officers need to pay attention to their neat and pleasant appearance in service, everyday in the office or during business visits.

2. Customers expect a neat and comfortable office environment that needs to be improved

3. Officers have not been responsive to the response to handling problems and can provide solutions experienced by customers.

4. Customers are not satisfied with the services expected from logistic businesses who always replace the services of transport companies

5. The business owner has not fulfilled the information and dissemination of payment methods for the use of goods delivery services in stages or installments.

6. The speed of delivery of goods does not match customer expectations.

7. Business owners have not been promoting continuously in the media.

The results of the test of influence between variables

Table 2:-Effect of Directly Between Variables

\begin{tabular}{|r|r|r|r|}
\hline Influence between Variables & Value of Influence & Statistic Value $\mathrm{t}$ & Influence \\
\hline $\mathrm{KP} \rightarrow \mathrm{KK}$ & 0,13 & 0.61 & Not significant \\
\hline $\mathrm{KP} \rightarrow \mathrm{LY}$ & 0,13 & $-1,84$ & Not significant \\
\hline $\mathrm{DTA} \rightarrow \mathrm{KK}$ & $-0,15$ & 2.21 & Significant \\
\hline $\mathrm{DTA} \rightarrow \mathrm{LY}$ & 0,11 & 1.46 & Not significant \\
\hline $\mathrm{DTA} \rightarrow \mathrm{PP}$ & 0,09 & -0.51 & Not significant \\
\hline $\mathrm{PR} \rightarrow \mathrm{KK}$ & 0,12 & 0,05 & Not significant \\
\hline $\mathrm{PR} \rightarrow \mathrm{LY}$ & 0,12 & -1.07 & Not significant \\
\hline $\mathrm{KK} \rightarrow \mathrm{PP}$ & 0.08 & 0.52 & Not significant \\
\hline $\mathrm{LY} \rightarrow \mathrm{PP}$ & 0,08 & 0,45 & \\
\hline
\end{tabular}

Source: As if Researchers, 2019.

Based on Table 1.2. the direct effect between variables from the results of the structural model analysis that shows a causal relationship or the effect of one latent variable on another latent, can be explained as follows:

\section{Hypothesis H1 - Effect of service quality on customer satisfaction}

Statistical Test Results the magnitude of the effect of service quality on customer satisfaction, namely: 0.13 statistical value $t$ count 0.61 under the $t$ table statistics (for $\alpha 5 \%$ and 2 -way test the value is 1.96), therefore $t$ count value $<\mathrm{t}$ table, then the null hypothesis is accepted, so it is concluded that service quality has no effect on customer satisfaction.

\section{H2 Hypothesis - Effect of service quality on loyalty.}

Statistical Test Results the magnitude of influence of service quality influences loyalty, namely: 0.13 statistical value $t$ count -1.84 under the $t$ table statistics (for $\alpha 5 \%$ and 2-way test the value is 1.96 ), therefore $t$ count value $<\mathrm{t}$ table, then the null hypothesis is accepted, so it is concluded that service quality has no effect on loyalty.

H3 Hypothesis - Effect of alternative attractiveness on customer satisfaction.

Statistical Test Results the magnitude of the influence of alternative attractiveness on consumer satisfaction, namely: -0.15 the statistical value $t$ count 2.21 above the $t$ table statistics (for $\alpha 5 \%$ and 2 -way test the value is 1.96), therefore the value of $\mathrm{t}$ count $<\mathrm{t}$ table, then the null hypothesis is rejected, so it can be concluded that alternative attractiveness influences consumer satisfaction 
H4 Hypothesis - Effect of Alternative attractiveness on loyalty

Statistical Test Results the magnitude of the influence of alternative attractiveness on loyalty, namely: 0.11 statistical value $t$ count 1.46 above the $t$ table statistics (for $\alpha 5 \%$ and 2 -way test the value is 1.96), therefore $t$ count value $<\mathrm{t}$ table, then the null hypothesis is accepted, so it is concluded that alternative appeal has no effect on loyalty.

\section{Hypothesis $\mathrm{H5}$ - The influence of alternative attractiveness on customer movement}

Statistical Test Results the magnitude of the influence of alternative attractiveness to customer movement, namely: 0.09 statistical value $t$ count 0.51 under the $t$ table statistics (for $\alpha 5 \%$ and 2 -way test the value is 1.96 ), therefore $t$ count value <t table, then the null hypothesis is accepted, so it is concluded that alternative appeal has no effect on customer movement.

\section{Hypothesis H6 - Effect of relational marketing on customer satisfaction.}

The results of the statistical test of the magnitude of relational marketing to customer satisfaction, namely: -0.12 statistical value of $t$ count 0.05 under the $t$ table statistics (for $\alpha 5 \%$ and 2 -way test the value is 1.96 ), therefore $t$ count value $<\mathrm{t}$ table, then the null hypothesis is accepted, so it is concluded that relational marketing has no effect on customer satisfaction

\section{Hypothesis H7 - The Effect of Relational Marketing on Loyalty}

Statistical Test results relational marketing magnitude on loyalty, namely: 0.12 statistical value $t$ count 1.07 under the $t$ table statistics (for $\alpha 5 \%$ and 2-way test the value is 1.96 ), therefore $t$ count value $<t$ table, then the null hypothesis is accepted, so it is concluded that relational marketing has no effect on loyalty.

\section{Hypothesis $\mathrm{H8}$ - Effect of customer satisfaction on customer movement}

Statistical results of the magnitude of the influence of customer satisfaction on customer movement, namely: 0.09 statistical value $t$ count -0.51 below / above the $t$ table statistics (for $\alpha 5 \%$ and 2 -way test the value is 1.96), therefore the value of $\mathrm{t}$ count $<\mathrm{t}$ table, then the null hypothesis is accepted, so it can be concluded that customer satisfaction has no effect on customer movement

\section{Hypothesis H9 - Effect of loyalty on customer movement}

Statistical results of the magnitude of the effect of Loyalty on customer movement, namely: 0.08 statistical values $t$ count 0.45 below / above the $\mathrm{t}$ table statistics (for $\alpha 5 \%$ and 2 -way test the value is 1.96), therefore the value of $\mathrm{t}$ count $<\mathrm{t}$ table, then the null hypothesis is accepted, so it is concluded Loyalty has no effect on customer movement.

Influence between variables through moderation variables

Table 3:-Effects between variables through moderation variables

\begin{tabular}{|l|l|l|l|l|}
\hline Ploting & $\begin{array}{l}\text { Intervening } \\
\text { Variable }\end{array}$ & Direct Influence & Indirect Influence & Total influence \\
\hline KP $\rightarrow$ PP & KK & & $0,13 \times 0.09=0,012$ & \\
\hline PR $\rightarrow$ PP & KK & 0,08 & $0,12 \times 0,09=0,011$ & $-0,07$ \\
\hline DTA $\rightarrow$ PP & KK & & $0,15 \times 0,09=0,014$ & \\
\hline KK $\rightarrow$ PP & LY & & $0,13 \times 0,08=0,010$ & \\
\hline PR $\rightarrow$ PP & LY & 0,08 & $0,12 \times 0,08=0,010$ & $-0,07$ \\
\hline DTA $\rightarrow$ PP & LY & & $0,11 \times 0,08=0,009$ & \\
\hline
\end{tabular}

Source: Processed by Researchers, 2019

Based on Tebel 3 above, an indirect effect is explained.

1. The indirect effect between the customer satisfaction variable on the customer movement variable through the consumer satisfaction moderation variable of 0.012 . This states that the variable customer satisfaction has a role that is not so big for the influence of customer movement. When viewed from the quality of service quality does not affect customer satisfaction.

2. The indirect effect between relational marketing on customer movement through consumer satisfaction moderation variable of 0.011 . If the effect totaled -0.07 when compared directly relational marketing to customer movement of 0.08 This states that the relational marketing variable has such a big role for the influence of customer movement. 
3. The indirect effect between alternative appeal to customer movement through moderation variables of customer satisfaction of 0.14 . This suggests that the alternative attractiveness variable has no role for the influence of customer movement. When viewed from the alternative attractiveness affects consumer satisfaction.

4. The effect is indirectly between the customer satisfaction variables on the variable customer movement through loyalty moderation variable of 0.010 . This states that the variable customer satisfaction has a role that is not so big for the influence of customer movement. When viewed from the quality of service does not affect loyalty.

5. The indirect effect between relational marketing on customer movement through loyalty moderation variable of 0.010. If the effect totaled -0.07 when compared directly relational marketing to customer movement of 0.08 This suggests that the relational marketing variable has a role that is not so big for the influence of customer movement. When viewed from relational marketing the effect on loyalty.

6. The indirect effect between alternative appeal to customer movement through loyalty moderation variable of 0.009. This suggests that the alternative attractiveness variable has a role to influence customer movement. When viewed from the alternative attraction affects the loyalty.

\title{
Discussion:- \\ Quality of service to customer satisfaction
}

Based on the calculation of the results of statistical tests of service quality on customer satisfaction is not significant this is different from previous studies Yuen and Thai (2015) that service quality affects customer satisfaction. Likewise, Hu and Huang (2011) stated that the significant influence between service quality on customer satisfaction of transportation services. and Celik and Cebi (200), that the quality of service really influences the satisfaction of transport service customers in Turkey. This is due to the many complaints found in the field regarding the timeliness, responsiveness of officers and compensation of officers in providing services to consumers.

\section{Quality of service to loyalty}

Based on the results of statistical tests that the quality of service is not significant to loyalty which is contrary to previous research Yang and Chao (2017). Service quality is also influenced by customer loyalty. This is the quality of services provided to consumers in transportation services that are not in line with the expectations and desires of customers and are experiencing delays in shipping goods by companies. If the incident repeatedly consumers will be disappointed and do not dare to provide references to other consumers to use the company's freight forwarding services. The impact of consumers will move to competing companies.

\begin{abstract}
Alternative appeal to consumer satisfaction.
Based on the results of statistical tests that alternative attraction affects customer satisfaction. This is in accordance with previous studies Yildiz (2017), concluded that there is a positive relationship between the attractiveness of alternatives to customer satisfaction. As we know, the alternative attraction is an attractive non-physical appearance that can support a product or advertisement (Greenwood, 2012). Cheng and Lee (2018), concluded that the alternative attraction is the quality of services offered by competitors that are different and better than the services provided by the company before, the company is difficult to contact when consumers need urgent information, both information speed in delivery and slow document making process thus creating consumer dissatisfaction
\end{abstract}

\section{Alternative appeal to loyalty}

Based on the results of statistical tests that alternative attractiveness does not affect loyalty which is contrary to the results of previous studies, namely Shimp (2007), Wu (2011) and Chuah et al, (2017). This needs to pay attention and improve services so that they become loyal customers, caused by various things, especially consumer disappointment in the process of shipping goods, guarantee the integrity of the package until the destination is in good condition.

\section{Altenative Attraction to Customer Movements}

Based on the results of statistical tests that alternative attractiveness is not significant to Customer Displacement where this is contrary to previous research The results of Yang and Chao's research (2017) in Taiwan, concluded that there was a significant influence between relational marketing to customer satisfaction. Likewise, the results of a study by Wittman (2014) in America, concluded that the quality of a publisher given by the airline Soutwets Airline affected passenger satisfaction. The alternative appeal offered to consumers in transportation services does not affect the movement of customers, because mainly on the factor of personal approach and information obtained while shipping goods, guarantee the delivery package to the destination. customer satisfaction and trust in shipping and prices do not match customer desires. 


\section{Marketing is relational to customer satisfaction}

Based on the results of statistical tests that relational marketing influences consumer satisfaction and is supported by research results Yildiz E (2017), states there is a relationship between relational marketing and customer satisfaction. In maintaining consumer satisfaction, one of the strategies is to implement relational marketing by creating communicative two-way communication and information that is easily understood and understood so that in cultivating a mutually beneficial relationship between consumers and sea transport companies.

\section{Marketing is relational to loyalty}

Based on the results of statistical tests that relational marketing has no effect on loyalty and contrary to previous research Griffin and Ebert (2017), states that the relationship between relational marketing and loyalty has a very significant relationship. Likewise, Mogha research results; Khodshidi and Menhaj (2014) there is a significant influence between relationship marketing and customer loyalty. According to researchers, each company has competitors from companies engaged in the same field and companies should pay attention to providing services to consumers, sometimes the company is less consistent between the rules that apply with the application of the field that is not in accordance with the expectations and desires of consumers impact on consumer loyalty to the company is reduced.

\section{Consumer satisfaction with customer movement}

Based on the results of statistical tests that customer satisfaction does not affect customer movement that is contrary to previous studies Zeithaml (2010) which concluded that customer satisfaction is related to customer movement. Likewise Bansal, Taylor and James (2005) identified that the quality of service provided was the reason for the formation of customer satisfaction and movement. This is due to the quality of services offered not in accordance with consumer expectations and promotions offered by the company

\section{Loyalty to customer movement}

Based on the results of statistical tests that loyalty has no effect on customer movement which is contrary to the research of Johan, et al (2014), which states that sea transport service companies show company loyalty which has an impact on customer movement. Therefore, companies must communicate to consumers who are more intensive and provide solutions with fast respone so that it is good so that companies do not change frequently to transport service competitors.

\section{Cycles and suggestions.}

\section{Conclusion:-}

The effect of one variable with other variables proved positive and significant, namely;

1. Superstitious variables have a positive effect on the product. This can be seen in the items of belief of business owners or entrepreneurs of cultural background or family who believe in superstition, their impact on the prodok trademark, which uses packaging, sentences that have meaning, symbols, speech and colors.

2. The product has a positive effect on marketing performance. This can be seen in the product items that are easy to say, easy to remember, have symbols, meanings or positive images that will make it easier for consumers to re-do transactions or buy back products sold in their businesses that will have an impact on marketing performance.

3. Local superstition has a positive effect on marketing performance in the product medium, except local superstition has a negative effect on marketing performance. This points to the belief that shamans, increasing the performance of the market, need product facilities as intermediaries.

\section{Suggestion}

Some of the suggestions presented based on this research have strengths and weaknesses. It is expected to be beneficial for businesses, consumers, and in determining marketing strategies in marketing products, but it needs to be considered for further evaluation in improving marketing performance, as well as paying attention to trusted superstitions. as

1. Paying attention to the use of taboo symbols on marketed products it is necessary to consider local cultural values related to superstition.

2. Maintain the quality and attractiveness of product packaging by considering the superstitious beliefs that are trusted by the local community 


\section{Reference:-}

1. Ahmad, Muhammad; Bilal, Ejaz Wasay dan Saif Ullah Malik (2012) Impact of Employee Motivation on Customer Satisfaction Study of Airline Industry In Pakistan. Interdisciplinary Journal of Contemporary Research In Busines, Vol. 4, No. 6.

2. Aprilianto, Rizky; Abdul Hakim dan Ainul Hayat (2014). Implementasi Asas Cabotage Dalam Kebijakan Pelayaran di Indonesia. Jurnal Administrasi Publik (JAP), Vol. 2, No.4, Hal. 758-764 |

3. Arfaecian; Firouzeh dan Sirion Chaipoopirutana (2014). A Study of The Antecedentt of Brand trust: A Case Study of Low Cost Airline in Bangkok, In International Conference on Business, Law and Corporate Social Responsibility (ICBLCSR'14) Oct 1-2, 2014 Phuket, Thailand (pp. 16-20).

4. Babbar, Sunil, dan Koufteros Xenophon (2008). The Human Element in Airline Service Quality: Contact Personnel and The Customer. International Journal of Operation and Production Management, 28 (9), Pages. 804-830.

5. Bansal Harvir S, Taylor Shirley F dan Yannik St.James.(2005)." Migrating to New Service Providers: Toward a Unifying Framework of Consumers' Switching Behaviors'.Journal og The Academy of Marketing.vol 33/1,Pp 96-115.

6. Bansal Harvir S., Irving P Gregory, dan Taylor Shirley F. (2004).” A Tree-Component Model of Customer Commitment to Service Provider". Journal of academy of Marketing.vol 2/3, Pages 234-250.

7. Berry, L.L. (1995). Relationship Marketing of Service - Growing Interest, Emerging Perspectives. Journal of the Academy of Marketing Science, Vol 23, No.4. pages 236-245.

8. Bui, T. B. (2011). Multimodal sea Transportation with Thailand-Cambodia-Vietnam transport countries in : Vietnam a case and study in Laos-Singapore relationship of routes. World Maritime University, no 148, .

9. Celik Metin dan Selcuk Cebi (2009). Proposing competitive strategies on Turkish Container port in maritim transportation network . Istambul technical university International Journal Vol.362,

10. Chaisumpunsakul, Wipaporn dan Pholphirul Piriya. (2017). Does international trade promote international tourism demand? Evidence from Thailand's trading partners. Kasetsart Journal of Social Sciences Vol. 39. Issue 3 pages 393-400.

11. Chen, C-H. dan Lee, H-Y. (2008). Empirical Analysis of the Customer Loyalty Problem in the International Logistics Market, WSEAS Transactions on Business and Economics, Iss. 4, Vol. 5, Pages 113-123.

12. Fugazza, Marco dan Hoffmann,Jan (2017). Liner shipping connectivity as determinant of trade. Jounal Of Shipping and Trade. Vol. 2.(1)

13. Garvin, David A. (1987). Competing on the the Eight Dimesion of Qauality, Harvard Business Review No.87603.

14. Gordon Fullerton. (2004). When Does Commitment Lead to Loyalty . Journal Service Research Vol 5/4 Pages 333-344

15. Grønholdt L dan Martensen, A. (2006). Key Marketing Performance Measures. The Marketing Review, Vol. 3, pages 243-252

16. Gronroos, Christian.(1984). A Service Quality Model and its Marketing implications. European journal of Marketing, Vol.18 No.4 pages 36-44

17. Gummesson, E. ( 2007 ) “Exit Service Marekting - Enter Service Marketing”.Journal of Customer Behaviour, 6. Pages $113-114$.

18. Gures, Nuriye, Seda Arslan, dan Sevil Yucel Tuun (2014). Custumer Expectation, Satisfaction and Loyalty Relationship in Turkish Airline Industry, International Journal of Marketing Studies; Vol. 6, No. 1

19. Hamza Salim Karim (2013). Airline Image and Service Quality Effect on Traveling Customers' Behavioral Intentions in Jordan. Europan Journal of Busines and Management. Vol. 5, No. 22.

20. Han, Xiaoyun, Robert J. Kwortnik dan Chunxiao Wang (2008). Service Loyalty: A Integrative Model and Examination Across service Contexts, Journal International of Service Research. Vol.11 (1) Pages 22-42.

21. Hill, Jimmy dan Pauric McGowan. (1999). "A qualitative approach to developing small firm marketing planning competencies", Qualitative Market Research: An International Journal, Vol.2, No.3, Pages 167-175

22. Hoppner, Jessica J; Griffith, David A dan White, Ryan C (2015). Reciprocity in Relationship Marketing: A Cross-Cultural Examination of the Effects of Equivalence and Immediacy on Relationship Quality and Satisfaction with Performance. Journal of International Marketing Vol.23 No.4 pages 64-83.

23. Hu, Kai Chieh. dan Huang, Mei. Chieh. (2011). Effects of Service Quality, Innovation and Corporate Image on Customer's Satisfaction and Loyalty of Air Cargo Terminal. International Journal of Operations Research, Vol. 8, No. 4, 36-47

24. Iordanoaia Florin (2013 ). The influences of Marketing Particular in Shipping. Journal Constanta Maritime University Annals Vol 17, No.1 Pages 279-286. 
25. Jan, Muhamhad Tahir ;Kalthom Abdullah dan Mustapha Hadj Smail (2013). Antecedents of loyalty in the Airline Industry of Malaysia. Busines research, Kuala Lumpur Malaysia.

26. Jang, H. M., Marlow, P. B. dan Mitroussi, K. (2013). The Effect of Logistics Service Quality on Customer Loyalty through Relationship Quality in the Container Shipping Context. Transportation Journal, Vol. 52, No. 4, Pages 493-521

27. Jean - Pie Gauci - Maistre (2009). Shipping Strategies in Dry bulk and Tanker Markets: Specialisation versys Diversification. Dissertation, World Maritime University Dissertations, 115,

28. Johan, Mohd Noor, Bahar, Yan dan Ping (2014).Factor Affecting Customer Loyalty Toward Airline Industry in Malaysia: An Explonatory Analysis. International Journal of Contemporary Research Business, Vol. 6, No. 6,

29. Kadarisman, Muh; Yuliantini dan Majid,Suharto Abdul. ( 2016) Formulasi Kebijakan Sistem Transportasi Laut. Jurnal Manajemen Transportasi \& logistik Vol.03 No2. Pages 163-183.

30. Kavirathna Chathumi A., Kawasaki, Tomoya., Hanaoka, Sshinya. and Matsuda, Ttakuma. (2018). Transshipment hub port selection criteria by shipping lines: the case of hub ports around the bay of Bengal. Journal of Shipping and Trade,zz .Vol. 3(4).

31. Kotler, Philip dan Keller Kevin Lane. (2012). Manajemen Pemasaran (Edisi Kedua Belas), Cetakan Ketiga: PT. Indeks. Jakarta.

32. Liang, Lena Jingen, dan Joppe, Marion (2018); Exploring the relationship between satisfaction, trust and switching intention, repurchase intention in the context of Airbnb. International Journal of Hospitality Management. Vol. 69:page 41-48

33. Lerrthaitrakul, Weerawit dan Vinai panjakajornsak (2014). The Airline Service Quality Affecting Post purchase Behavioral Intention Empirical Evidence from the Low Cost Air line Industry. International Journal of Trade, Economics and Finance, Vol. 5, No. 2,

34. Lin, L-H., Chen, K.K. dan Chiu, R-H. (2017). Predicting Customer Retention Likelihood In The Container Shipping Industry Through The Decision Tree Approach. Journal of Marine Science and Technology, Vol. 25, No. 1, Pages 23-33

35. Lovelock, C.H dan Gummesson E. (2004). Whither services marketing? In search of new paradigm and fresh perpective. Journal of service research Vol.7 No.1, pages 20-41

36. Ndubisi, N.O., Malhotra, N.K. \& Chan, K.W. 2009. 'Relationship marketing, customer satisfaction and loyalty: a theoretical and empirical analysis from an Asian perspective', Journal of International Consumer Marketing, Vol 21. No.1.

37. Mark Johnson ( 2015 ) M Johnson, C Mena - International Journal of Production Economics, 2015.

38. Martín, Consuegra Molina, dan Esteban (2009). An Integrated Model of Price, Satisfaction and Loyality: An Empircal Analysis in the Service Sector; Journal of Product and Brand Management, No. 167, Pages 459-468,

39. Mittal Vikas dan Kamakura Wagner A (2001).Satisfaction, Repurcharse Intent and Repurcharse Behaviour : Investigating the Moderating effect of Customer Characteristic. Jurnal of Marketing Research Vol XXXVIII, Pages 131-142.

40. Moghadam, Tabriz, Khorshidi, dan Menhaj (2014). Investigating the Influence of Relationship Quality on Passengers' Loyalty in Airline Industry. International Business and management Vol. 8, no. 2, 2014, pp. 14-40

41. Mochtar Kusumaatmadja ( 1994) Pendidikan Hukum di di indonesia, Jurnal Hukum dan Pembangunana,Vol 24.No.6.

42. Nor Sara Nadia; Muhammad Yunus; Jamil Bojei, dan Wan Edura Wan Rashid (2013). Service Quality towards Customer Loyalty in Malaysia"s Domestik Low Cost Airline Services. International Journal of Education, Business, Management and e-Learning, Vol. 3, No. 4.

43. Cristiane Pizzutti dos Santos dan Daniel Von der Hayde Fernandes (2008),. Antecedents and Consequences of Consumer Trust in The Context of Service Recovery. Brazilian Administration Review (BAR). Vol.5 No.3 Pages 225-224.

44. Sarker, S. M. Abu Nayem (2015). Freight Forwarding Industry: Function, Economic Role and Future Market in Bangladesh. Bangladesh Maritime Journal (BMJ) Vol. 1, Issue- 1 pages 93-98.

45. Sekaran, Uma dan Bougie Roger, (2010). Research Methods For Business: buku kedua penerbit Erlangga Jakarta.

46. Shin,SooYong dan Pak, Myong Sop. (2016). The Critical Factors for Korean Freight Forwarders' Purchasing Negotiation in International Logistics. The Asian Journal of Shipping and Logistics Vol 32. Isuue 4 pages 195201

47. Shin, Seungjin; Roh ,Hong-Seung dan Hur, Sung Ho (2018). Characteristics Analysis of Freight Mode Choice Model According to the Introduction of a New Freight Transport System. Journal Sustainability. vol. 11 (4) page 1-13. 
48. Sitichai Charoensettasilp dan Chong Wu (2013). Thai Passenger's Satisfaction after Receiving Services from Thailand's Domestic Low Cost Airline. International Journal Vol. 6, No. 6,

49. Subhashini S dan Preetha, S.. (2018). An empirical analysis of service quality factors pertaining to ocean freight forwarding services. Maritime Business Review, Vol. 3 Issue: 3, Pages.276-289.

50. Sys, Christa; Hilde Meersman and Eddy Van De Voorde.(2011). A non-structural test for competition in the container liner shipping industry. Journal Maritime Policy \& Management, Vol. 38, issue 3, pages 219-234

51. Sumenda, Graciella Eunike.(2017). Keberadaan asas Cabotage terhadap Perusahaan Angkutan Laut dalam Undang-Undang Nomor 17 tahun 2008 Tentang Pelayaran, Jurnal Lex et Societatis, Vol. V. No 7

52. Van den Bos, Gertjan dan Bart Wiegmans (2018) hort sea shipping: a statistical analysis of influencing factors on SSS in European countries. Journal of Shipping and Trade,zz .Vol. 3(6).

53. Wittman, M.D (2014), Are Low-Cost Carrier Passengers Less Likely To Complain About Sevice Quality. Journal of Air Transport Management, Vol. 35, Pages. 64-71.

54. Yang, C-C dan Chao, C-C. (2017). How relationship marketing, switching costs and service quality impact customer satisfaction and loyalty in Taiwan's airfreight forwarding industry?", A: Transport Science, DOI: Fatima 10.1080 / 23249935.2017 .1321696

55. Yasvari, Tahmoures Hasangholipour, Reza Abachian Ghassemi, dan Elnaz Rahrovy (2012). Influental Factors on Word of Mouth in Service . Industries Internasional journal of Learningf \& Development , Vol. 2, No. 5, ISNN: 2164-4063.

56. Yeo, G. I , Thai, V.V., dan Roh, S. Y. (2015). An Analysis of Port Service Quality and Customer Satisfaction: The Case of Korean Container Ports, The Asian Journal of Shipping and Logistics, Vol. 31, No. 4

57. Yildiz, E. (2017). Effects Of Service Quality On Customer Satisfaction, Trust, Customer Loyalty And Word Of Mouth: An Application On Cargo Companies In Gümüşhane. Global Journal of Economics and Business Studies, Vol. 6, Iss. 12, Pages 81-88.

58. Yuen dan Thai (2015).Service quality and customer satisfaction in liner shipping. International Journal of Quality and Service Sciences, Vol. 7 Iss 2/3, Pages 170-183.

59. Zhicheng Qin (2012). The Factor Influencing Low cost Air Line Passenger SatisFaction and Loyalty in Bangkok, Thailand. Disertation, University of Thai Chamber of Comerce. 